\title{
Identification of vector-borne pathogens in dogs and cats from Southern Brazil
}

\author{
J. Malheiros ${ }^{a, *}$, M.M. Costa ${ }^{b}$, R.B. do Amaral ${ }^{c}$, K.C.M. de Sousa ${ }^{c}$, M.R. Andréc, \\ R.Z. Machado ${ }^{c}$, M.I.B. Vieira ${ }^{\mathrm{a}}$ \\ a Programa de Pós-graduação em Bioexperimentação, Faculdade de Agronomia e Medicina Veterinária, Universidade de Passo Fundo (UPF), Passo Fundo, \\ RS, Brazil \\ ${ }^{\mathrm{b}}$ Laboratório de Análises Clínicas Veterinárias, Faculdade de Agronomia e Medicina Veterinária, Universidade de Passo Fundo (UPF), Passo Fundo, RS, Brazil

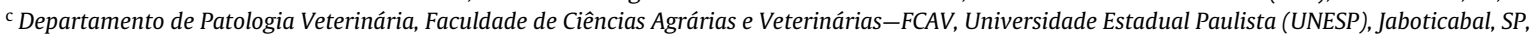 \\ Brazil
}

\section{A R T I C L E I N F O}

\section{Article history:}

Received 3 August 2015

Received in revised form 11 April 2016

Accepted 12 April 2016

Available online 13 April 2016

\section{Keywords:}

VBD

Ticks

Brazil

Dogs

Cats

PCR

\begin{abstract}
A B S T R A C T
Dogs and cats are often infected with vector-borne pathogens and play a crucial role as reservoirs and hosts in their life cycles. The aim of the present study was to investigate the occurrence of vector-borne pathogens among dogs and cats in the northwestern region of Rio Grande do Sul (RS) State, Brazil. One hundred and ten blood samples were collected from dogs $(n=80)$ and cats $(n=30)$. Laboratory analysis were carried out through stained blood smears, indirect enzyme-linked immunosorbent assay (ELISA) for Babesia vogeli and Ehrlichia canis (only for dogs) and polymerase chain reaction (PCR) aiming the detection of pathogens. The following pathogens were screened by PCR among dogs and cats: Babesia spp. and Hepatozoon spp. (18S rRNA gene), Anaplasma spp. (16S rRNA gene), and Ehrlichia spp. (dsb gene for dogs and 16S rRNA gene for cats) and Bartonella spp. (nuoG gene only for cats). Using blood smears structures morphologically compatible with piroplasms were found in $5.45 \%(6 / 110)$ of the samples. AntiB. vogeli and anti-E. canis antibodies were detected in $91 \%$ (73/80) and 9\% (7/80) of the dogs, respectively. All the seropositive dogs to E. canis were also to B. vogeli. Nineteen (17.3\%) animals were positive to hemoparasites by PCR. After sequencing Rangelia vitalii 6/80 (7.5\%), B. vogeli 3/80 (4\%), Hepatozoon spp. $1 / 80$ (1\%), and Anaplasma spp. $1 / 80$ (1\%) were found in the dogs, and B. vogeli $2 / 30(7 \%)$ and Bartonella spp. $6 / 30$ (20\%) were detected in the screened cats. No sample was positive for genes $d s b$ and 165 rRNA of Ehrlichia spp. Only those animals which were positive for $R$. vitalii showed findings compatible with rangeliosis, such as anemia (100\%), thrombocytopenia (67\%), jaundice (50\%), external bleeding (50\%), and anorexia (50\%). This is the first time that B. vogeli detected among cats in Southern Brazil.
\end{abstract}

(c) 2016 Elsevier GmbH. All rights reserved.

\section{Introduction}

Humans and animals that live in tropical and subtropical regions have been brought to desolation by injury of parasitic diseases around the world (Dantas Torres and Otranto, 2014). In this context, vector-borne diseases (VBD) are known as important emerging and re-emerging illnesses (Vilhena et al., 2013), which are ubiquitous and easily disseminated (Maia et al., 2015). Babesia spp. (Schnittger et al., 2012), Rangelia vitalii (Fighera et al., 2010), Hepatozoon spp. (Aydin et al., 2015), Ehrlichia spp. (Corales et al., 2014), Anaplasma spp. (Aktas et al., 2015), and Bartonella spp. (Mogollon-Pasapera

\footnotetext{
* Corresponding author.

E-mail addresses: jenifermalheiros@hotmail.com, jenifer@unicruz.edu.br (J. Malheiros).
}

et al., 2009; Chomel et al., 2014) have been pointed out as important VBD pathogens that infect the animals such as domestic animals.

In Brazil, Babesia vogeli and Ehrlichia canis are transmitted by the tick Rhipicephalus sanguineus sensu lato (s.l.), whereas $R$. vitalii is transmitted by Amblyomma aureolatum (Dantas-Torres and Otranto, 2014). Hepatozoon canis is admittedly transmitted by $R$. sanguineus s.l.; however, in this country, studies have demonstrated that transmission also occurs by Amblyomma ovale (Forlano et al., 2005; Demoner et al., 2013). Although A. phagocytophilum is transmitted by ticks of the genus Ixodes in several regions of the world, this agent has been molecularly detected in Amblyomma cajennense and $R$. sanguineus s.l. ticks in Brazil (Santos et al., 2013). A. platys seems to be transmitted by $R$. sanguineus s.l. (Cardoso et al., 2015; Maia et al., 2015), but Brazilian epidemiological data also suggest its transmission by A. cajennense (Dahmani et al., 2015). On 
the other hand, Bartonella is transmitted by fleas, lice, and phlebotomines. Nonetheless, the DNA of this bacterium was detected in flies (Chomel and Kasten, 2010; Telford and Wormser, 2010; Yao et al., 2011) and the vector competence of Ixodes ricinus tick for $B$. birtlesii and B. henselae has been proven (Cotté et al., 2008; Reis et al., 2011).

Dogs and cats are often infected with vector-borne pathogens and play a crucial role as reservoirs and hosts in their life cycles (Day, 2011; Maia et al., 2015). Given the impact of VBD, studies have been conducted to determine their geographical prevalence (Yuasa et al., 2012). In Brazil, dogs and cats may harbor a wide variety of parasitic agents; however, information on their distribution and epidemiology is still fragmented (Dantas-Torres and Otranto, 2014). Therefore, the aim of the present study was to investigate the occurrence of vector-borne pathogens in dogs and cats in the northwestern region of Rio Grande do Sul (RS) State, Brazil.

\section{Materials and methods}

\subsection{Ethical statement}

This study was approved by the Committee on Animal Research and Ethics of Universidade de Passo Fundo, RS, Brazil, protocol no. $015 / 2014$.

\subsection{Blood specimens from dogs and cats}

Blood samples were collected in EDTA tubes from dogs $(n=80)$ and cats $(n=30)$ treated at the Veterinary Hospital of Universidade de Passo Fundo (HV-UPF), in Passo Fundo, in the northwestern region of RS, Brazil, between June and December 2014. Animals with clinical signs (jaundice, pale mucous, epistaxis, splenomegaly) and/or blood disorders (anemia, leukopenia or leukocytosis and thrombocytopenia), presence of ticks (routine procedure), or which had been referred for surgical sterilization and no clinical signs and hematological alterations compatible with VBD (elective procedure) were included in the present study. Blood was collected by venipuncture and used in serological and molecular tests. A blood sample was collected from the pinna in order to obtain blood smears and later staining by Giemsa and Panotic methods.

\subsection{Serology}

The presence of anti-B. vogeli and anti-E. canis IgG antibodies in the serum of dogs was identified by indirect enzyme-linked immunosorbent assay (ELISA) using a commercially available kit (Imunodot Diagnósticos Ltda $^{\circledR}$, Brazil) for each pathogen researched. Optical density (OD) was calculated from the average of negative controls x 2.5, according to the manufacturer's instructions. The serological analysis of cats was not be performed.

\subsection{PCR amplification and sequencing}

The DNA was extracted from the blood samples using a commercially available kit (DNeasy Blood \& Tissue Kit ${ }^{\circledR}$, Qiagen, Hilden, Germany), following the manufacturer's extraction protocol. To verify the existence of amplifiable DNA in the samples, a PCR assay for the housekeeping gene glyceraldehyde-3-phosphate dehydrogenase (GAPDH) was performed as previously described (Birkenheuer et al., 2003).

The following agents were screened by PCR: Babesia spp., Hepatozoon spp., Anaplasma spp., Ehrlichia spp. and Bartonella spp. The PCR was carried out according to the protocols previously described for genes 18S rRNA of Babesia spp. (Jefferies et al., 2007) and Hepatozoon spp. (O'Dwyer et al., 2013), $16 S$ rRNA of Anaplasma spp. (Massung et al., 1998), and Ehrlichia spp. (Murphy et al., 1998), dsb of Ehrlichia spp. (Doyle et al., 2005), and nuoG of Bartonella spp. (André et al., 2015a). Table 1 provides information on primers and reaction conditions. Hepatozoon sp., Ehrlichia canis, and Bartonella spp. DNA-positive controls were obtained from naturally infected cats from Campo Grande, MS, Brazil (André et al., 2015a; André et al., 2015b). Anaplasma sp. DNA positive control was obtained from a naturally infected dog from Campo Grande, MS, Brazil (Sousa et al., 2013).

After amplification by conventional PCR assays, the amplicons were subjected to $1 \%$ agarose gel electrophoresis and stained with ethidium bromide. The positive PCR products were purified using Silica Bead DNA Gel Extraction Kit (Fermentas, Lithuania). The sequencing of $18 \mathrm{~S}$ rRNA gene for Babesia spp. and Hepatozoon spp., and 16S rRNA gene for Anaplasma spp. was carried out using the BigDye $^{\circledR}$ Terminator v3.1Cycle Sequencing Kit and ABI PRISM 310 DNA Analyzer (Applied Biosystems ${ }^{\circledR}$ ).

\subsection{Phylogenetic analysis}

Consensus sequences were obtained through the analysis of the sense and antisense sequences using the CAP3 program (http:// mobyle.pasteur.fr/cgi-bin/MobylePortal/portal.py). Comparisons with sequences deposited in GenBank were done using the basic local alignment search tool (BLAST) (Altschul et al., 1990). The sequences were aligned with sequences published in GenBank using Clustal/W (Thompson et al., 1994) in Bioedit v. 7.0.5.3 (Hall, 1999). Phylogenetic inference was based on maximum likelihood (ML) inference. The ML phylogenies were inferred with RAxMLHPC BlackBox 7.6.3 software (Stamatakis et al., 2008) (which includes an estimation of bootstrap node support) through the CIPRES Science Gateway (Miller et al., 2010), using a GTR + GAMMA model of evolution and 1000 bootstrapping replicates. The best model of evolution was selected by the program jModelTest 2 on XSEDE (Darriba et al., 2012) under the Akaike Information Criterion (AIC) (Posada et al., 2004), through the CIPRES Science Gateway (Miller et al., 2010). The trees were visualized in Treegraph 2.0.56-381 beta (Stover and Muller, 2010).

\section{Results}

The results of blood smears, serology and PCR-positive animals submitted to elective procedures and routine ones are shown in Table 2.

\subsection{Blood smears}

Structures morphologically compatible with piroplasms were found in 6 (5.45\%) dogs (Fig. 1).

\subsection{Serology}

The serum samples of dogs with OD value higher than 0.3325 and 0.4175 were considered to be positive for the presence of anti- $B$. vogeli and anti-E. canis antibodies, respectively. Among the sampled dogs, 91\% (73/80) were seropositive for B. vogeli and 9\% (7/80) for E. canis. Interestingly, all dogs seropositive to $E$. canis also showed seropositivy for $B$. vogeli.

\subsection{PCR and sequencing}

The PCR-positive samples are shown in Table 3. All the PCRs for the $16 S$ rRNA and $d s b$ of Ehrlichia spp. were negatives. At the time of collection, 50\% (3/6) of dogs positive for $R$. vitalii, and both dogs positive for Hepatozoon spp. and Anaplasma spp. were infested by ticks, which unfortunately were not identified. 
Table 1

Primer sets for PCR amplification of VBD pathogens.

\begin{tabular}{|c|c|c|c|c|c|}
\hline Pathogen & Gene & Primers and Probes $\left(5^{\prime}-3^{\prime}\right)$ & $\begin{array}{l}\text { Product } \\
\text { size (bp) }\end{array}$ & PCR conditions & Reference \\
\hline Babesia spp. (n-PCR) & 18S rRNA & $\begin{array}{l}\text { BTF1 GGCTCATTACAACAGTTATAG } \\
\text { BTR1CCCAAAGACTTTGATTTCTCTC } \\
\text { BTF2CCGTGCTAATTGTAGGGCTAATAC BTR2 } \\
\text { GGACTACGACGGTATCTGATCG }\end{array}$ & 790 & $\begin{array}{l}\left.1^{\circ}\right) 94{ }^{\circ} \mathrm{C} 3 \mathrm{~min}, 58^{\circ} \mathrm{C} 1 \mathrm{~min} \text {, } \\
72^{\circ} \mathrm{C} 2 \mathrm{~min}, 45 \text { cycles } \\
\left(94^{\circ} \mathrm{C} 30 \mathrm{~s}, 58^{\circ} \mathrm{C} 20 \mathrm{~s}, 72^{\circ} \mathrm{C}\right. \\
\left.30 \mathrm{~s}), 72^{\circ} \mathrm{C} 7 \mathrm{~min}, 2^{\circ}\right) \text { Just } \\
\text { the annealing temperature } \\
\text { was increased to } 62^{\circ} \mathrm{C} \text {. }\end{array}$ & $\begin{array}{l}\text { Jefferies et al., } \\
2007\end{array}$ \\
\hline Hepatozoon spp. & 18S rRNA & $\begin{array}{l}\text { HepF300 GTTTCTGACCTATCAGCTTTCGACG } \\
\text { Hep900CAAATCTAAGAATTTC ACCTCTGAC }\end{array}$ & 581 & $\begin{array}{l}94^{\circ} \mathrm{C} 3 \mathrm{~min}, 35 \text { cycles } \\
\left(94^{\circ} \mathrm{C} 45 \mathrm{sec}, 56^{\circ} \mathrm{C} 1 \mathrm{~min}\right. \\
\left.72^{\circ} \mathrm{C} 1 \mathrm{~min}\right), 72^{\circ} \mathrm{C} 7 \mathrm{~min}\end{array}$ & $\begin{array}{l}\text { O'Dwyer et al., } \\
2013\end{array}$ \\
\hline Anaplasma spp. (n-PCR) & 16S rRNA & $\begin{array}{l}\text { ge3a CACATGCAAGTCGAACGGATTATTC ge10r } \\
\text { TTCCGTTAAGAAGGATCTAATCTCC ge9f } \\
\text { AACGGATTATTCTTTATAGCTTGCT) ge } 2 \\
\text { GGCAGTATTAAAAGCAGCTCCAGG }\end{array}$ & 546 & $\begin{array}{l}\left.1^{\circ}\right) 95^{\circ} \mathrm{C} 2 \mathrm{~min}, 40 \text { cycles } \\
\left(94^{\circ} \mathrm{C} 30 \mathrm{~s}, 55^{\circ} \mathrm{C} 30 \mathrm{~s}, 72^{\circ}\right. \\
\left.1 \mathrm{~min}), 72^{\circ} \mathrm{C} 5 \mathrm{~min}, 2^{\circ}\right) \text { The } \\
\text { same conditions were as } \\
\text { described, except that } 30 \\
\text { cycles were used. }\end{array}$ & $\begin{array}{l}\text { Massung et al. } \\
1998\end{array}$ \\
\hline Ehrlichia spp. (n-PCR) & 16S rRNA & $\begin{array}{l}\text { ECC AGAACGAACGCTGGCGGCAAGC ECB } \\
\text { CGTATTACCGCGGCTGCTGGCA HE3 } \\
\text { TATAGGTACCGTCATTATCTTCCCTAT } \\
\text { ECAN5CAATTATTTATAGCCTCTGGCTATAGGA }\end{array}$ & 396 & $\begin{array}{l}\left.1^{\circ}\right) 94^{\circ} \mathrm{C} 3 \mathrm{~min}, 30 \text { cycles } \\
94^{\circ} \mathrm{C} 1 \mathrm{~min}, 65^{\circ} \mathrm{C} 2 \mathrm{~min} \text {, } \\
\left.72^{\circ} \mathrm{C} 2 \mathrm{~min} .2^{\circ}\right) 3 \text { cycles } \\
94^{\circ} \mathrm{C} 1 \mathrm{~min}, 55^{\circ} \mathrm{C} 2 \mathrm{~min} \text {, } \\
72^{\circ} \mathrm{C} 1.5 \mathrm{~min} .\end{array}$ & $\begin{array}{l}\text { Murphy et al., } \\
1998\end{array}$ \\
\hline Ehrlichia spp. (qPCR) & dsb & $\begin{array}{l}321 \text { TTGCAAAATGATGTCTGAAGATATGAAACA } \\
671 \text { GCTGCTCCACCAATAAATGTATCYCCTA } \\
\text { PROBE FAM } \\
\text { AGCTAGTGCTGCTTGGGCAACTTTGAGTGAA } \\
\text { BHQ-1 }\end{array}$ & 409 & $\begin{array}{l}95^{\circ} \mathrm{C} 5 \mathrm{~min}, 40 \text { cycles } 95^{\circ} \mathrm{C} \\
15 \mathrm{~s}, 60^{\circ} \mathrm{C} 1 \mathrm{~min} .\end{array}$ & $\begin{array}{l}\text { Doyle et al., } \\
2005\end{array}$ \\
\hline Bartonella spp. (qPCR) & nuoG & $\begin{array}{l}\text { F-Bart CAATCTTCTTTTGCTTCACC R-Bart } \\
\text { TCAGGGCTTTATGTGAATAC PROBE TEXAS RED } \\
\text { TTYGTCATTTGAACACG BHQ2a-Q }\end{array}$ & 93 & $\begin{array}{l}95^{\circ} \mathrm{C} 3 \mathrm{~min}, 40 \text { cycles } 95^{\circ} \mathrm{C} \\
10 \mathrm{~min}, 52,8^{\circ} \mathrm{C} 30 \mathrm{sec} .\end{array}$ & $\begin{array}{l}\text { André et al., } \\
\text { 2015a,b }\end{array}$ \\
\hline
\end{tabular}

Table 2

Results of the blood smear, ELISA and PCR according to the type of procedure.

\begin{tabular}{|c|c|c|c|c|c|}
\hline \multirow[t]{2}{*}{ Animals } & \multicolumn{2}{|c|}{ Procedure } & \multicolumn{3}{|l|}{ Diagnosis } \\
\hline & Elective & Routine & Blood Smear & ELISA B. canis and E. canis & PCR \\
\hline Dog 52 & & $\mathrm{X}$ & $\mathrm{N}$ & 1 & Anaplasma spp. \\
\hline Dog 69 & & $\mathrm{X}$ & $\mathrm{N}$ & $\mathrm{N}$ & Hepatozoon spp. \\
\hline Dog 86 & $\mathrm{X}$ & & $\mathrm{N}$ & 1 & Babesia vogeli \\
\hline Dog 94 & $\mathrm{X}$ & & $\mathrm{N}$ & 1 & Babesia vogeli \\
\hline Dog 98 & & $\mathrm{X}$ & Piroplasms & 1 & Rangelia vitalii \\
\hline Dog 102 & $\mathrm{X}$ & & $\mathrm{N}$ & $\mathrm{N}$ & Babesia vogeli \\
\hline Dog 106 & & $\mathrm{X}$ & Piroplasms & 2 & Rangeia vitalii \\
\hline Dog 107 & & $\mathrm{X}$ & Piroplasms & 2 & Rangelia vitalii \\
\hline Dog 108 & & $\mathrm{X}$ & Piroplasms & 1 & Rangelia vitalii \\
\hline Dog 109 & & $\mathrm{X}$ & Piroplasms & 1 & Rangelia vitalii \\
\hline Dog 110 & & $\mathrm{X}$ & Piroplasms & 1 & Rangelia vitalii \\
\hline Cat 31 & & $\mathrm{X}$ & $\mathrm{N}$ & - & Bartonella spp. \\
\hline Cat 71 & $\mathrm{X}$ & & $\mathrm{N}$ & - & Bartonella spp. \\
\hline Cat 72 & $\mathrm{X}$ & & $\mathrm{N}$ & - & Bartonella spp. \\
\hline Cat 73 & $\mathrm{X}$ & & $\mathrm{N}$ & - & Babesia vogeli \\
\hline Cat 74 & $\mathrm{X}$ & & $\mathrm{N}$ & - & Bartonella spp. \\
\hline Cat 82 & $\mathrm{x}$ & & $\mathrm{N}$ & - & Bartonella spp. \\
\hline Cat 84 & $\mathrm{X}$ & & $\mathrm{N}$ & - & Bartonella spp. \\
\hline Cat 100 & $\mathrm{X}$ & & $\mathrm{N}$ & - & Babesia vogeli \\
\hline
\end{tabular}

$\mathrm{N}$ : negative. 1 : B. canis. 2 : E. canis.

Table 3

The genetic sequencing results.

\begin{tabular}{|c|c|c|c|}
\hline Animals & PCR & GenBank access number ${ }^{\mathrm{a}}$ & GenBank (BLAST) similarity (\%) \\
\hline Dog 98 & 18S rRNA Babesia spp. & КТ323926 & Rangelia vitalii KF218606 - 99\% \\
\hline Dog 106 & 18S rRNA Babesia spp. & KT323927 & Rangelia vitalii KF218606-99\% \\
\hline Dog 107 & 18S rRNA Babesia spp. & KT323928 & Rangelia vitalii KF218606 - 99\% \\
\hline Dog 108 & 18S rRNA Babesia spp. & KT323931 & Rangelia vitalii KF218606 - 99\% \\
\hline Dog 109 & 18S rRNA Babesia spp. & КТ323929 & Rangelia vitalii KF218606 - 99\% \\
\hline Dog 110 & 18S rRNA Babesia spp. & KT323920 & Rangelia vitalii KF218606 - 99\% \\
\hline Dog 86 & 18S rRNA Babesia spp. & KT323933 & Babesia vogeli HM590440 - 100\% \\
\hline Dog 94 & 18S rRNA Babesia spp. & KT323934 & Babesia vogeli HM590440 - 100\% \\
\hline Dog102 & 18S rRNA Babesia spp. & KT323936 & Babesia vogeli HM590440 - 100\% \\
\hline Cat 73 & 18S rRNA Babesia spp. & KT323932 & Babesia vogeli HM590440 - 100\% \\
\hline Cat 100 & 18S rRNA Babesia spp. & KT323935 & Babesia vogeli HM590440 - 100\% \\
\hline Dog 69 & 18S rRNA Hepatozoon spp. & KT323037 & Hepatozoon canis AY150067 - 100\% (Spanish Fox) \\
\hline Dog 52 & 16S rRNA Anaplasma spp. & KT323925 & Anaplasma phagocytophilum CP006618 - 100\% (European sample) \\
\hline
\end{tabular}

a Access number of positive samples in this study deposited in GenBank. 


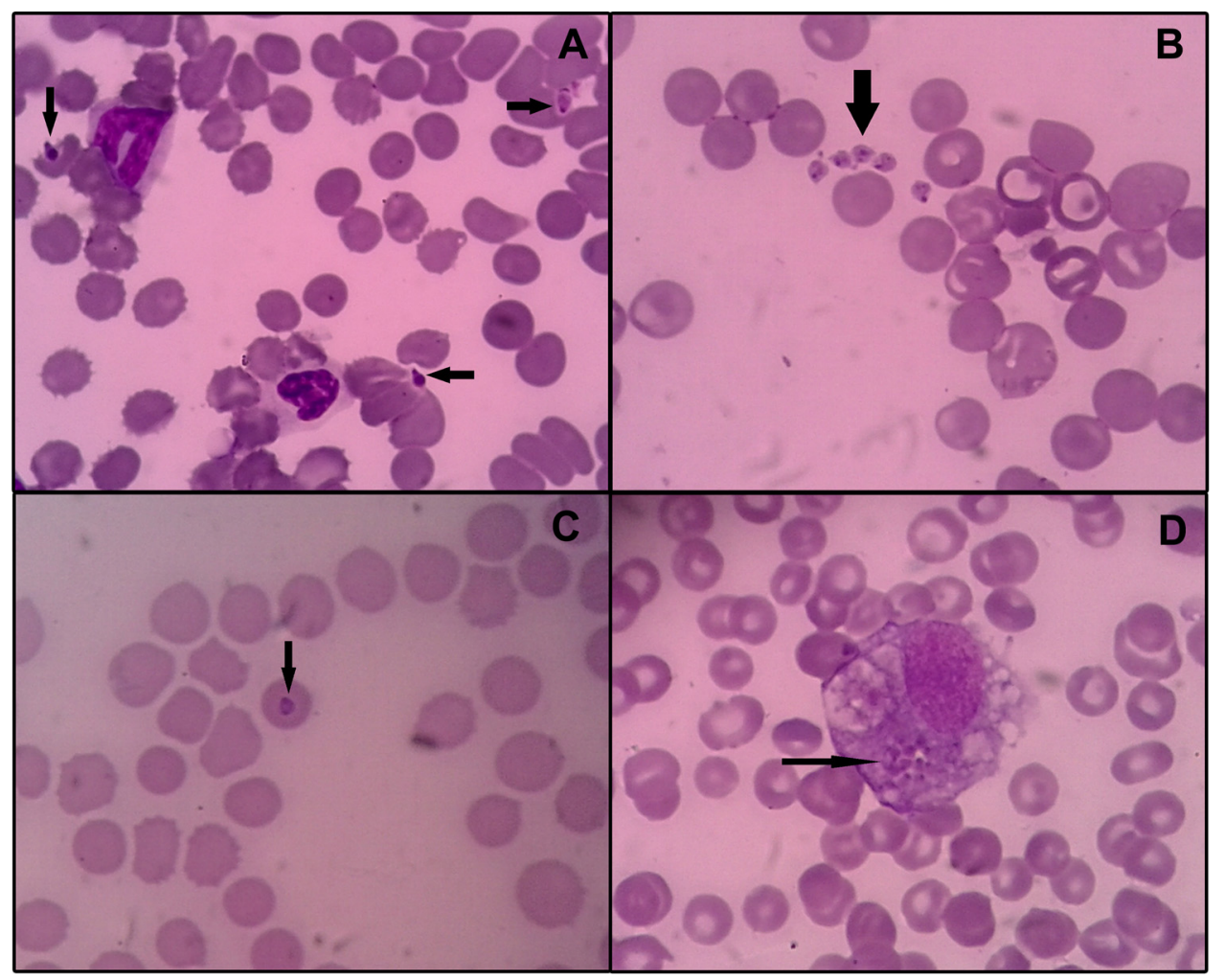

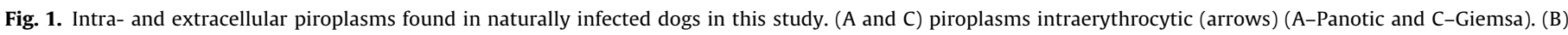
Extracellular piroplasms (arrow) (Panotic). (D) Piroplasms within a macrophage (arrow) (Panotic) (1000×).

\subsection{Phylogenetic analysis}

The phylogenetic tree of the sample positive for the 18S rRNA of Babesia spp. (Fig. 2) showed that the six isolated positive for $R$. vitalii by PCR were located in the same clade of the group of $R$. vitalii detected in domestic dogs in RS and wild carnivores of the species Cerdocyoun thous (GenBank accession numbers HQ150006 and KF964151, respectively). By the isolated sequences from dog and cats positive for Babesia spp. by PCR, they presented in the same clade of Babesia vogeli (value bootstrap 99/100).

Phylogenetically, the isolated PCR positive for Hepatozoon was found within the same clade of $H$. canis (value bootstrap 92/100) detected in a red fox from Porto Alegre, RS, Brazil by Criado-Fornelio et al. (2006) (Fig. 3).

The positive fragments of the 16S rRNA gene of Anaplasma spp. presented in the same clade of $A$. phagocytophilum (value bootstrap 80/100) isolated by European dog (GU236670) (Fig. 4).

\section{Discussion}

Dogs and cats are the most popular animals worldwide (DantasTorres and Otranto, 2014). In Brazil, the Instituto Brasileiro de Geografia e Estatística (IBGE) data indicate that $44.3 \%$ of households have at least one dog and $11.7 \%$ at least one cat. Unfortunately, some arthropods such as fleas, lice and ticks can transmit pathogens to these animals, like bacteria and protozoa (Dantas-Torres and Otranto, 2014).

The pathogen E. canis has been reported around the world, mainly in tropical and subtropical regions (Dantas-Torres and Otranto, 2011). Frequently, E. canis is detected in dogs in several regions of Brazil (Vieira et al., 2013), but in Southern region only Aguiar et al. (2013) detected E. canis by PCR in dogs the State of Paraná. By investigating the context in which $R$. sanguineus s.l. is a vector for E. canis, Moraes-Filho et al. (2011) observed the presence of two lineages of this tick. The temperate lineage (from Spain) was detected in RS, Brazil (where the present study was undertaken); Chile; Argentina and Uruguay; and tropical lineage (from South Africa) detected in other Brazilian regions. In Mexico, an study found no molecular evidence of transmission of $E$. canis by lineage temperate of $R$. sanguineus s.l. (Almazán et al., 2016). Furthermore, recently, Moraes-Filho et al. (2015) showed that temperate lineage has no vectorial competence to transmit $E$. canis.

On the other hand, serological tests for the detection of anti-E. canis antibodies revealed $9 \%$ (7/80) of positive dogs. Similarly, the study of Krawczak et al. (2012), conducted in the central region of RS, showed $4.43 \%$ of seropositive animals for E. canis in the immunofluorescence assay. However, the research of Lasta et al. (2013) did not detect any seropositive animal, in the city of Porto Alegre, state capital of RS. According to the Krawczak et al. (2012), cross-reactions with other species of Ehrlichia, or even with other agents of the family Anaplasmataceae might occur but, in this study, the only dog that was positive for Anaplasma spp. was not positive for $E$. canis.

The detection of $A$. platys by PCR may range from $7.8 \%$ to $88 \%$ in Brazil (Santos et al., 2013). In RS, the detection of this pathogen is described in the study of Lasta et al. (2013), who found $14.07 \%$ of positive dogs in PCR. In addition, A. platys has also been reported in cats in Brazil (Lima et al., 2010; Correa et al., 2011), but no cat was positive in our study. On the other hand, few are the reports on molecular detection of A. phagocytophilum in Brazil (Santos et al., 2011; Santos et al., 2013; Silveira et al., 2015). Our study indicates the presence of Anaplasma spp. closely related to A. phagocytophilum (GU236670, bootstrap value 80/100). Additionally, Anaplasma spp. closely related to A. phagocytophilum has been detected in wild carnivores (André et al., 2012), wild birds 


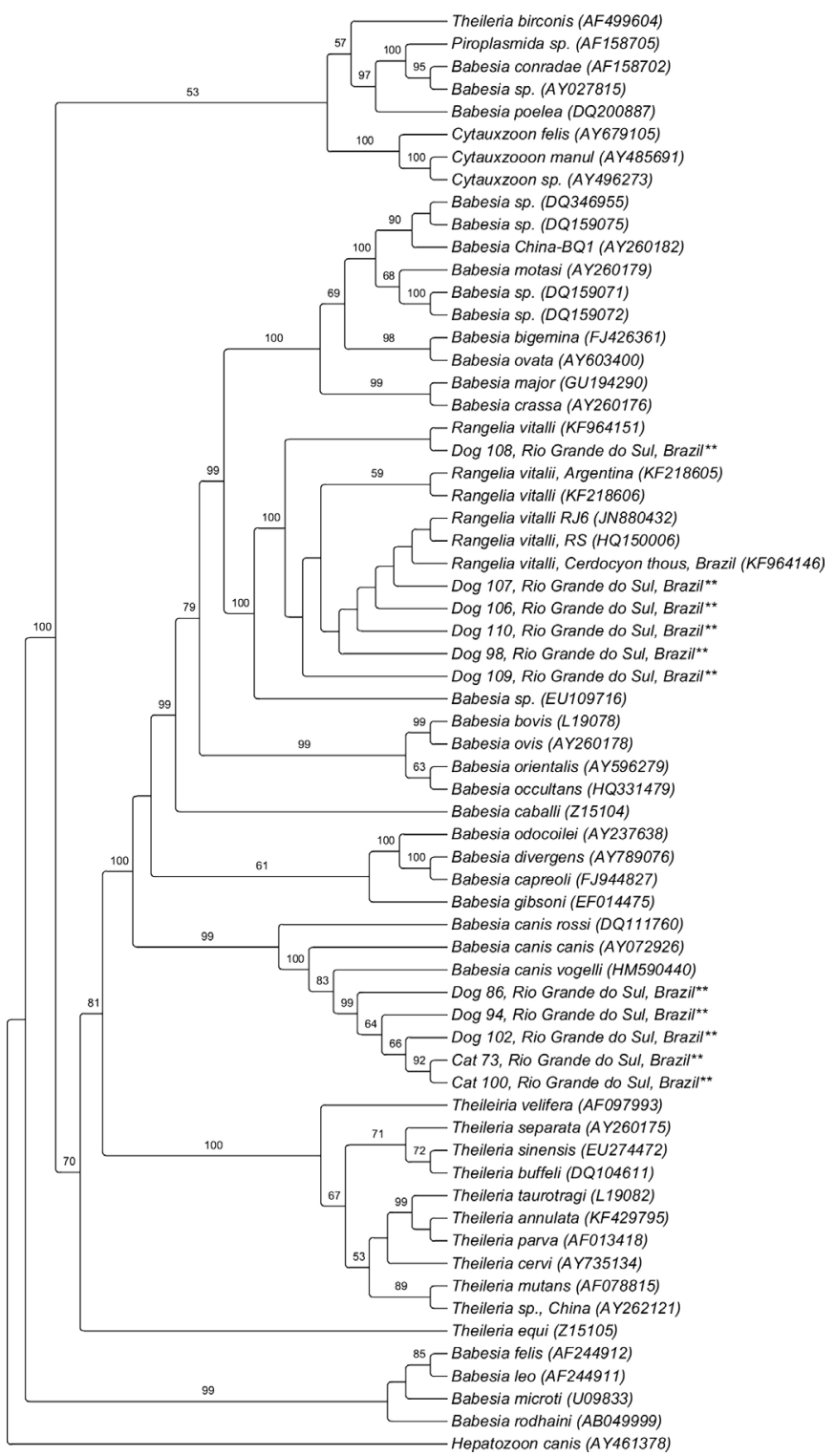

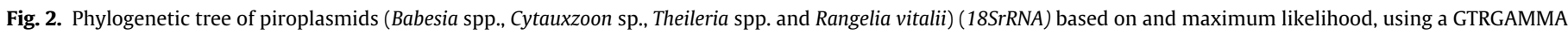
model of evolution. Numbers correspond to bootstrap values over 50. **Samples from the present study.

(Machado et al., 2012), wild deer (Silveira et al., 2014), and freeroaming cats (André et al., 2014) in Brazil.

Regarding rangeliosis, after been overlooked for over 50 years, is currently regarded as a re-emerging disease in Brazil (Soares et al., 2014). Reports of infected canids are more frequent in the southern and southeastern regions, including the states of Rio de Janeiro (RJ) (Lemos et al., 2012), São Paulo (SP) (Pestana, 1910; Carini and Maciel, 1914), and RS (Loretti and Barros, 2005; Fighera et al., 2010). Aside from Brazil, rangeliosis has already been described in Argentina (Eiras et al., 2014) and in Uruguay (Sarasúa and Donati, 1976; Soares et al., 2015), countries where A. aureolatum is also found (Guglielmone et al., 2002; Venzal et al., 2005). In RS, where the disease appears to be more common, a retrospective study of Fighera et al. (2010) identified 35 cases of $R$. vitalii infection in necropsy and histopathological samples examined from 1985 to 2009. Besides these studies, other ones conducted in $\mathrm{RS}$ in recent years demonstrate the presence of $R$. vitalii in dogs (Krauspenhar et al., 2003; Soares et al., 2011), including a study of ours about domestic dogs in which four positive animals were detected (Gottlieb, 2014), in addition to positive results for one wild carnivore (Soares et al., 2014). Based on these results, we suggest that further studies be carried out in other regions of RS and across Brazil in order to get to know the current epidemiological profile of the disease.

$B$. vogeli has already been identified in Africa, Asia, Europe, Americas, and Australia. In Brazil, B. vogeli and B. gibsoni are the species identified in dogs so far (Passos et al., 2005; Trapp et al., 2006; Dantas-Torres and Otranto, 2014); nevertheless, the vector for B. gibsoni has not been detected in Brazil yet (Trapp et al., 2006). On the other hand, $R$. sanguineus s.l.is widely distributed in Brazil and adapts well to urban areas, which may contribute towards the endemic status of babesiosis in some Brazilian regions (Costa et al., 2015). Furthermore, dog-specific Babesia species have been sporadically detected by molecular methods in cats, also in Brazil, where new Babesia spp. and Theileria spp. genotypes related to ruminant and equine piroplasmosis have been recently reported in cats in southeastern and midwestern regions of Brazil (André et al., 2014, 2015a), thus highlighting the need for molecular characterization of circulating piroplasmids in pets. 


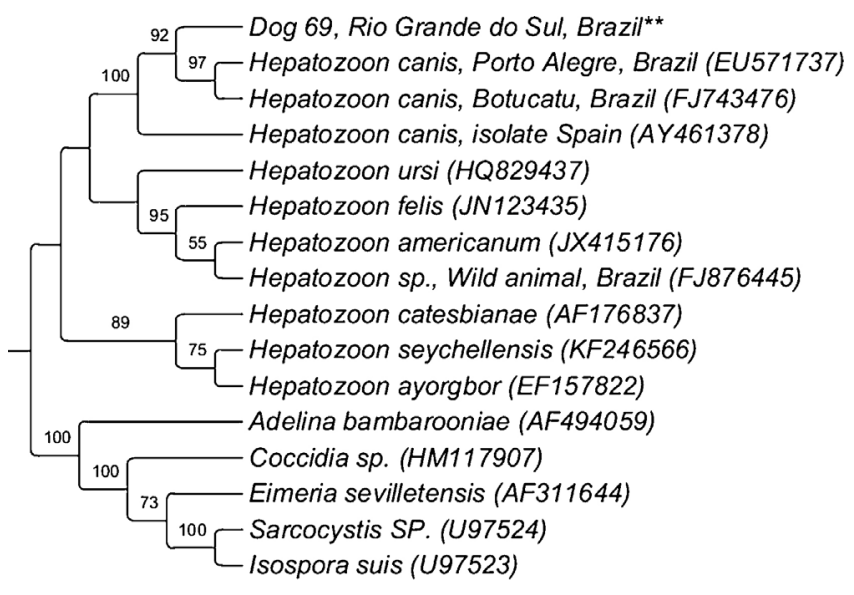

Fig. 3. Phylogenetic tree of Hepatozoon spp. (18SrRNA) based on and maximum likelihood, using a GTRGAMMA model of evolution. Numbers correspond to bootstrap values over $50 .{ }^{* *}$ Samples from the present study.

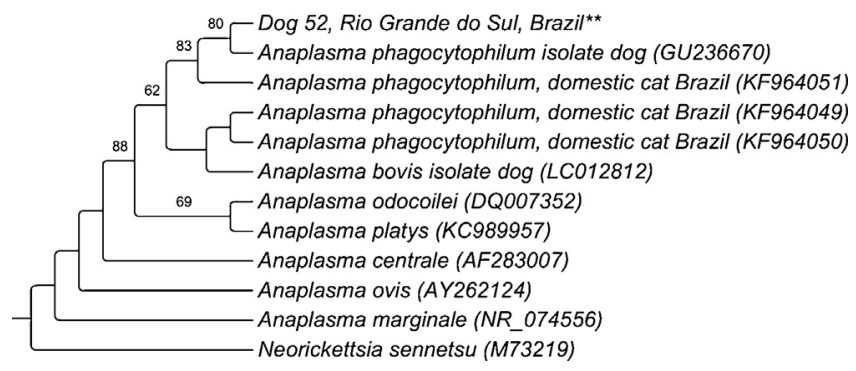

Fig. 4. Phylogenetic tree of Anaplasma spp. (16SrRNA) based on and maximum likelihood, using a GTRGAMMA model of evolution. Numbers correspond to bootstrap values over $50 .{ }^{* *}$ Samples from the present study.

We detected seropositive results for B. vogeli in $91 \%$ of the tested dogs, but Vieira et al. (2013) found $60.3 \%$ of positive dogs in indirect immunofluorescence (IIF), also in southern Brazil. In this study, out of $91 \%, 2$ of 3 PCR-positive dogs for B. vogeli were also seropositive. Therefore, the animals tested herein were assumed to be in the chronic stage of the disease, which is often asymptomatic (Schnittger et al., 2012). Consequently, the levels of circulating parasites were below the PCR detection threshold, which, according to some authors (Birkenheuer et al., 2004; Jefferies et al., 2007; Irwin, 2009), may lead to false-negative results at this stage. Moreover, cross-reactions with antigens of other piroplasmids, such as $R$. vitalii, might have occurred when all the animals with positive PCR results for $R$. vitalii were considered to be also positive in the serum tests for anti-B. vogeli antibodies. So, what is known that $A$. aureolatum, tick involved in the transmission of $R$. vitalii, is found in this Brazilian state (Evans et al., 2000; Martins et al., 2010; Gauger et al., 2013; Soares et al., 2014) and also, unlike other Brazilian regions, the RS is not regarded as an endemic area for babesiosis. Additionally, seven animals were seropositive for anti-B. vogeli and anti-E. canis antibodies, including two positive dogs for $R$. vitalii in PCR, demonstrating possible exposure to these agents, as reported in other Brazilian studies (Trapp et al., 2006; Sousa et al., 2013). However, although $R$. sanguineus s.l. is potentially involved in the transmission of at least nine pathogens that infect dogs in Brazil (Dantas-Torres, 2008), the vectorial competence of temperate lineage of $R$. sanguineus s.l. found in RS for B. vogeli is still unknown.

Studies conducted in Brazil for research of Hepatozoon in dogs report levels of prevalence around 58\% (Spolidorio et al., 2009) and $67 \%$ (Rubini et al., 2005), or as high as $84.3 \%$ in dogs from a rural area in southeastern (Miranda et al., 2014). On the other hand, we found only one dog positive for Hepatozoon spp. in PCR, as well as in study of Lasta et al. (2009), which had already detected this pathogen in a dog in the city of Porto Alegre. Apart from these reports, there are no more records of the presence of Hepatozoon spp. in dogs in the RS and the face of such prevalence differences, Miranda et al. (2014) report that the prevalence rates for infection may vary depending on the study design, sampling method, characteristics of the canine population, vector distribution, and diagnostic methods.

The phylogenetic analysis showed Hepatozon in the same clade of $H$. canis detected in Spanish red foxes. However, another study performed in RS identified foxes infected with Hepatozoon phylogenetically related to $H$. americanum detected in canids from the USA (Criado-Fornelio et al., 2006). In addition to the detection of Hepatozoon in dogs, the present study did not find any positive cat despite the fact that $H$. canis (Rubini et al., 2008), H. felis (Bortoli et al., 2012) and a new genotype of Hepatozoon sp. (André et al., 2015b) have been occasionally reported in cats in Brazil.

According to previous studies performed in Brazil, the molecular prevalence of Bartonella in cats ranges from $4.3 \%$ to $97.3 \%$ (Souza et al., 2010; Staggemeier et al., 2010; Bortoli et al., 2012; Braga et al., 2012; Miceli et al., 2013; André et al., 2014, 2015b). In these studies, it is important to take into account the different molecular methods used (conventional PCR or qPCR), in addition to the type of sampled population (stray cats, owned cats, or catteries). In our study, the frequency of positive cats for Bartonella spp. was equal to $20 \%$, in which all animals were owned, but four of them lived in the same house, which could have facilitated transmission. Similar results were found by Miceli et al. (2013) and Staggemeier et al. (2014), who identified $17 \%$ and $25.53 \%$ of positive cats for Bartonella spp. in catteries in the state of Mato Grasso and RS, respectively.

None of the positive cats for Bartonella spp. in qPCR had clinical signs of infection. It is known that cats are the major reservoirs for B. henselae, B. clarridgeiae, and B. koehlerae, and that the infection is usually subclinical or shows nonspecific clinical signs (Maia et al., 2014). While Ctenocephalides fleas had been incriminated as vectors for B. henselae and B. clarridgeiae, Ixodes ticks have been pointed out as vectors for $B$. henselae and B. birtlesii (Cotté et al., 2008; Reis et al., 2011).

In this study, a higher frequency of positive animals was observed among animals submitted to elective procedures (14/19), probably because these animals could be chronic and asymptomatic carriers of these pathogens. Therefore, the only animals with positive blood smears with later molecular confirmation were those positive for $R$. vitalli (6/6), given that these animals had been submitted to routine procedures and were the only ones with acute disease compatible with rangeliosis at the time of collection. The isolates, consistent with those described in the literature (França et al., 2014), were anemia (100\%), thrombocytopenia (67\%), jaundice (50\%), external bleeding (50\%), and anorexia (50\%).

All of the other animals with positive PCR results had negative blood smears and showed no clinical and/or laboratory findings compatible with infection by their respective agents (data not shown). In this case, infected dogs and cats may sometimes present with nonspecific clinical signs, low parasitemia due to subclinical or chronic disease, hindering the diagnosis of VBD (Spolidorio et al., 2009; Solano-Gallego and Baneth, 2011; Maia et al., 2014). Furthermore, serological assays may have cross-reactions, and direct detection by blood smears has poor sensitivity and specificity. Thus, molecular methods play an important role in the detection and differentiation of these agents (Little, 2010).

\section{Conclusion}

This study shows the presence of $R$. vitalii, B. vogeli, Hepatozoon spp., Anaplasma spp. and Bartonella spp. in pets. In cats, B. vogeli is detected for the first time in this region, showing the need for 
more studies that aim to determine the role of these animals in the epidemiology of VBD.

Furthermore, we highlight the importance of pathogens research transmitted by arthropods in RS, Brazil, because, unlike other Brazilian regions, very little is known about the agents circulating in pets and wild animals and even more so, what are the vectors involved, which may hinder correct diagnosis, treatments and tick control measures in this region.

\section{Acknowledgments}

The authors would like to acknowledge the assistance and commitment of Immuno Parasitology Laboratory at the Universidade Estadual Paulista Julio Mesquita Filho, Jaboticabal Campus. We appreciate the support of Fundação de Amparo à Pesquisa do Rio Grande do Sul (FAPERGS) through scholarship. We also thank the Dr. João Fábio Soares for his contribution in correcting this article.

\section{References}

Aguiar, D.M., Melo, A.L., Pacheco, T.A., Zanutto, M.S., Horta, M.C., Santarém, V.A., Camargo, L.M., McBride, J.W., Labruna, M.B., 2013. Genetic diversity of Ehrlichia canis in Brazil. Vet. Microbiol. 164, 315-321.

Aktas, M., Özübek, S., Altay, K., Ipek, N.D.S., Balkaya, I., Utuk, A.E., Kirbas, A., Simsek, S., Dumanli, N., 2015. Molecular detection of tick-borne rickettsial and protozoan pathogens in domestic dogs from Turkey. Parasites Vectors 8, 157.

Almazán, C., González-Álvarez, V.H., de Mera, I.G.F., Cabezas-Cruz, A., Rodríguez-Martínez, R., de la Fuente, J., 2016. Molecular identification and characterization of Anaplasma platys and Ehrlichia canis in dogs in Mexico. Ticks Tick Borne Dis. 7, 276-283.

Altschul, S.F., Gish, W., Miller, W., Myers, E.W., Lipman, D.J., 1990. Basic localalignment search tool. J. Mol. Biol. 215, 403-410.

André, M.R., Denardi, N.C.B., de Souza, K.C.M., Gonçalves, L.R., Henrique, P.C., Ontivero, C.R.G.R., Gonzalez, I.H.L., Nery, C.V.C., Chagas, C.R.F., Monticelli, C., Santis, A.C.G., Machado, R.Z., 2014. Arthropod-borne pathogens circulating in freee-roaming domestic cats in a zoo environment in Brazil. Ticks Tick Borne Dis. 5, 545-551.

André, M.R., Dumler, J.S., Scorpio, D.G., Teixeira, R.H., Allegretti, S.M., Machado, R.Z., 2012. Molecular detection of tick-borne bacterial agents in brazilian and exotic captive carnivores. Ticks Tick Borne Dis. 3, 247-253.

André, M.R., Dumler, J.S., Herrera, H.M., Gonçalves, L.R., de Sousa, K.C., Scorpio, D.G., de Santis, A.C., Domingos, I.H., de Macedo, G.C., Machado, R.Z., 2015a. Assessment of a quantitative 5é nuclease real-time polymerase chain reaction using the nicotinamide adenine dinucleotide dehydrogenase gamma sununit (nuoG) for Bartonella species in domicilied and stray cats in Brazil. J. Feline Med. Surg., 1-9.

André, M.R., Herrera, H.M., Fernandes, S.J., Gonçalves, L.R., Domingos, I.H., de Macedo, G.C., Machado, R.Z., 2015b. Tick-borne agents in domesticated and stray cats from the city of Campo Grande, Mato Grosso do Sul, midwestern Brazil. Ticks Tick Borne Dis, http://dx.doi.org/10.1016/j.ttbdis.2015.07.004.

Aydin, M.F., Sevin, F., Sevin, M., 2015. Molecular detection and characterization of Hepatozoon spp. in dogs from the central part of Turkey. Ticks Tick Borne Dis. 6 , 388-392

Birkenheuer, A.J., Levy, M.G., Breitschwerdt, E.B., 2003. Development and evaluation of a seminested PCR for detection and differentiation os Babesia gibsoni (Asian genotype) and B. canis DNA in canine blood samples. J. Clin. Microbiol. 41, 4172-4177.

Birkenheuer, A.J., Levy, M.G., Breitschwerdt, E.B., 2004. Efficacy of combined atovaquone azithromycin for therapy of chronic Babesia gibsoni (Asian genotype) infections in dogs. J. Vet. Intern. Med. 18, 494-498.

Bortoli, C.P., André, M.R., Pinto, A.A., Machado, S.T.Z., Machado, R.Z., 2012. Detection of hemoplasma and Bartonella species and co-infection with retroviruses in cats subjected to a spaying/neutering program in Jaboticabal SP, Brazil. Rev. Bras. Parasitol. Vet. 21, 219-223.

Braga Mdo, S., Diniz, P.P., André, M.R., Bortoli, C.P., Machado, R.Z., 2012. Molecular characterisation of Bartonella species in cats from Séo Luãs, state of Maranhao, north-eastern Brazil. Mem. Inst. Oswaldo Cruz 107, 772-777.

Cardoso, L., Gilad, M., Cortes, H.C.E., Nachum-Biala, Y., Lopes, A.P., Vila-Voçosa, M.J., Simoes, M., Rodrigues, P.A., Baneth, G., 2015. First report of Anaplasma platys infection in red foxes (Vulpes vulpes) and molecular detection of Ehrlichia canis and Leishmania infantum in foxes from Portugal. Parasites Vectors 8, 144

Carini, A., Maciel, J., 1914. Sobre a moléstia dos cães chamada nambi-uvú, e o seu parasita (Rangelia vitalli). An. Paul. Med. Cirurg. 3, 65-71.

Chomel, B.B., Kasten, R.W., 2010. Bartonellosis, an increasingly recognized zoonosis. J. Appl. Microbiol. 109, 743-750.

Chomel, B.B., Kasten, R.W., Stuckey, M.J., Bretschwerdt, E.B., Maggi, R.G., Henn, J.B., Koehler, J.E., Chang, C., 2014. Experimental infection of cats with Afipia felis and various Bartonella species or subspecies. Vet. Microbiol. 172, 505-510.

Corales, J.M., Viloria, V.V., Venturina, V.M., Mingala, C.N., 2014. The prevalence of Ehrlichia canis, Anaplasma platys and Babesia spp. in dogs in Nueva Ecija,
Philippines based on multiplex polymerase chain reaction (mPCR) assay. Ann. Parasitol. 60, 267-272.

Correa, E.S., Paludo, G.R., Scalon, M.C., Machado, J.A., Lima, A.C.Q., Pinto, A.T.B., Thiebaut, J.T.L., Albernaz, A.P., 2011. Investigação molecular de Ehrlichia spp. e Anaplasma platys em felinos domésticos: alterações clínicas, hematológicas e bioquímicas. Pesquisa Vet. Bras. 31, 899-909.

Costa, A.P., Costa, F.B., Labruna, M.B., Silveira, I., Moraes-Filho, J., Soares, J.F. Spolidorio, M.G., Guerra, R.M.S.N.C., 2015. A serological and molecular survey of Babesia vogeli, Ehrlichia canis, and Rickettsia spp. among dogs in the state of Maranhão, northeastern Brazil. Braz. J. Vet. Parasitol. 24, 28-35.

Cotté, V., Bonnet, S., Le Rhun, D., Le Naour, E., Chauvin, A., Boulouis, H.J., Lilin, T., Vayssier-Taussat, M., 2008. Transmission of Bartonella henselae by Ixodes ricinus. Emerging Inf. Dis. 14, 1074-1080.

Criado-Fornelio, A., Ruas, J.L., Casado, N., Farias, N.A., Soares, M.P., Muller, G., Brumt, J.G., Berne, M.E., Buling-Sarana, A., Barba-Carretero, J.C., 2006. New molecular data on mammalian Hepatozoon species (Apicomplexa: adeorina) from Brazil and Spain. J. Parasitol. 92, 93-99.

Dahmani, M., Marié, J.L., Mediannikov, O., Raoult, D., Davoust, B., 2015. First identification of Anaplasma platys in the blood of dogs from French Guiana. Vector Borne Zoonotic Dis. 15, 170-172.

Dantas-Torres, F., Otranto, D., 2014. Dogs, cats, parasites, and humans in Brazil: opening the black box. Parasites Vectors 7, 22.

Dantas-Torres, F., 2008. Canine vector-borne diseases in Brazil. Parasites Vectors 1, 25.

Darriba, D., Taboada, G.L., Doalho, R., Posada, D., 2012. jModelTest 2: more models, new heuristics and parallel computing. Nat. Methods 9, 772.

Day, M.J., 2011. One health: the importance of companion animal vector-borne diseases. Parasites Vectors 4, 49

Demoner de, L.C., Rubini, A.S., Paduan Kdos, S., Metzgera, B., Antunes, de Paula, J.M.A., Martins, T.F., Mathias, M.I., O'Dwyer, L.H., 2013. Investigation of ticks vectors of Hepatozoon canis in Brazil. Ticks Tick Borne Dis. 4, 542-546.

Doyle, C.K., Labruna, M.B., Breitschwerdt, E.B., Tang, Y.W., Corsvet, R.E., Hegarty B.C., Bloch, K.C., Li, P., Walker, D.H., McBride, J.W., 2005. Detection of medically important Ehrlichia by quantitative multicolor TaqMan real-time polymerase chain reaction of the dsb gene. J. Mol. Diagn. 7, 504-510.

Eiras, D.F., Craviotto, M.B., Baneth, G., Moré, G., 2014. First report of Rangelia vitalii infection (canine rangeliosis) in Argentina. Parasitol. Int. 63, 729-734.

Evans, D.E., Martins, J.R., Guglielmone, A.A., 2000. A review of the ticks (Acari, Ixodida) of Brazil: their hosts and geographic distribuition -1 The state of Rio Grande do Sul, Southern Brazil. Mem. Inst. Oswaldo Cruz 95, 453-470.

Fighera, R.A., Souza, T.M., Kommers, G.G., Irigoyen, L.F., Barros, C.S.L., 2010. Patogênese e achados clínicos, hematológicos e anatomopatológicos da infecção por Rangelia vitalii em 35 cães (1985-2009). Pesq. Vet. Bras. 30, 974-987.

Forlano, M., Scofield, A., Fernandes, K.R., Ewing, S.A., Massard, C.L., 2005. Diagnosis of Hepatozoon spp. in Amblyomma ovale and its experimental transmission in domestic dogs in Brazil. Vet. Parasitol. 134, 1-7.

França, R.T., Silva, A.S., Loretti, A.P., Mazzanti, C.M., Lopes, S.T.A., 2014. Canine rangeliosis due to Rangelia vitalli: From first report in Brazil in 1910 to current day-a review. Ticks Tick Borne Dis. 5, 466-474.

Gauger, A.L., Vivan, C.C., Vieira, M.I.B., Andrade, C.G., Luz, H.R., Landulfo, G.A., Faccini, J.L.H., Barros-Batestti, D.M., 2013. Ticks in Dogs Trated at the Hospital of University of Passo Fundo-RS, Brasil. IV Simpósio Brasileiro de Acarologia, Rio Grande do Sul, Brazil.

Gottlieb, J., 2014. Babesia canis, Ehrlichia canis e Rangelia vitalii: Aspectos Clínicos, Parasitológicos, Hemato-sorológicos e Moleculares De cães Infectados Da Região De Passo Fundo-RS-Brasil [dissertation]. University of Passo Fundo, Passo Fundo.

Guglielmone, A.A., Mangold, A.J., Boero, C., Azcue, R., 2002. Nuevo registro de amblyomma aureolatum (Pallas, 1772) (=Amblyomma striatum Entre Rios, Argentina. Rev. FAVE Ci. Vet. 1

Hall, T.A., 1999. BioEdit: a user-friendly biological sequence alignment editor and analysis program for Windows 95/98/NT. Nucl. Acids Symp. Ser. 41, 95-98.

Instituto Brasileiro de Geografia e Estatística2013 Pesquisa Nacional de Saúde. www.ibge.gov.br/home/estatistica/populacao/pns/2013_vol2/default_xls.shtm.

Irwin, P.J., 2009. Canine babesiosis: from molecular taxonomy to control. Parasites Vectors 2, S4.

Jefferies, R., Ryan, U.M., Jardine, J., Robertson, I.D., Irwin, P.J., 2007. Babesia gibsoni: detection during experimental infections and after combined atovaquone and azithromycin therapy. Exp. Parasitol. 117, 115-123.

Krauspenhar, C., Fighera, R.A., Graça, D.L., 2003. Anemia hemolítica em cães associada a protozoários. Medvep Ver. Cientif. Med. Vet. Pequenos Anim. Anim. Estim. 1, 273-281.

Krawczak, F.S., Labruna, M.B., Sangioni, L.A., Vogel, F.S.F., Soares, J.F. Lopes, S.T.A. 2012. Serological survey on Ehrlichia sp: among dogs in the central region of Rio Grande do Sul. Ver. Parasitol. Vet. 21, 415-417.

Lasta, C.S., Santos, A.P., Mello, F.P.S., Lacerda, L.A., Messick, J.B., González, F.H.D., 2009. Infecção por Hepatozoon canis em canino doméstico na região Sul do Brasil confirmada por técnicas moleculares. Ciênc. Rural 39, 2135--2040.

Lasta, C.S., dos Santos, A.P., Messick, J.B., Oliveira, S.T., Biondo, A.W., Vieira, R.F.C., Dalmolin, M.L. González, F.H.D., 2013. Molecular detection os Ehrlichia canis and Anaplasma platys in dogs in southern Brazil. Rev. Bras. Parasitol. Vet. 22, 360-366.

Lemos, T.D., Cerqueira, A.M.F., Tomas, H.K., Silva, A.V., Corrêa, R.G.B., Paludo, G.R. 2012. Detection and molecular characterization of piroplasms species from 
naturally infected dogs in southeast Brazil. Rev. Bras. Parasitol. Vet. 21, $137-142$.

Lima, M.L.F., Soares, P.T., Ramos, C.A.N., Araújo, F.R., Ramos, R.A.N., Souza, I.I.F., Faustino, M.A.G., Alves, L.C.A., 2010. Molecular detection of Anaplasma platys in a naturally-infected cat in Brazil. Braz. J. Microbiol. 41, 381-385.

Little, S.E., 2010. Ehrlichiosis and anaplasmosis in dogs and cats. Vet. Clin. North Am. Small Anim. Pract. 40, 1121-1140.

Loretti, A.P., Barros, S.S., 2005. Hemorrhagic disease in dogs infected with an unclassified intraendothelial piroplasm in southern Brazil. Vet. Parasitol. 134, 193-213.

Machado, R.Z., André, M.R., Werther, K., de Sousa, E., Gavioli, F.A., Alves Jr, J.R.F., 2012. Migratory and carnivorous birds in Brazil: reservoirs for Anaplasma and Ehrlichia species? Vector Borne Zoonotic Dis. 8, 705-708.

Maia, C., Ramos, C., Coimbra, M., Bastos, F., Martins, A., Pinto, P., Nunes, M., Vieira, M.L., Cardoso, L., Campino, L., 2014. Bacterial and protozoal agents of feline vector-borne diseases in domestic and stray cats from southern Portugal. Parasites Vectors 7, 115.

Maia, C., Almeida, B., Coimbra, M., Fernandes, M.C., Cristovão, J.M., Ramos, C., Martins, A., Martinho, F., Silva, P., Neves, N., Nunes, M., Vieira, M.L., Cardoso, L., Campino, L., 2015. Bacterial and protozoal agents of canine vector-borne diseases in the blood of domestic and stray dogs from southern Portugal. Parasites Vectors 8, 138.

Martins, J.R., Reck Jr., J., Doyle, R.L., da Cruz, N.L.C., Vieira de, A.W.M., Souza, U.A., 2010. Amblyomma aureolatum (Acari: ixodidae) parasitizing margay (Leopardus wiedii) in Rio Grande do Sul. Rev. Bras. Parasitol Vet. 19, 189-191.

Massung, R.F., Slater, K., Owens, J.H., Nicholson, W.L., Mather, T.N., Solberg, V.B., Olson, J.G., 1998. Nested PCR assay for detection of granulocytic ehrlichiae. J. Clin. Microbiol. 36, 1090-1095.

Miceli, N.G., Gavioli, F.A., Gonçalves, L.R., André, M.R., Souza, K.C.M., de Machado, R.Z., 2013. Molecular detection of feline arthropod-borne pathogens in cats in Cuiabá, state of Mato Grosso, central-western region of Brazil. Rev. Bras Parasitol. Vet. 3, 385-390.

Miller, M.A., Pfeiffer, W., Schwartz, T., 2010. Creating the CIPRES Science Gateway for inference of large phylogenetic trees. In: Proceedings of the Gateway Computing Environments Workshop (GCE), New Orleans, LA, pp. 1-8.

Miranda, R.L., O’Dwyer, L.H., de Castro, J.R., Metzger, C.B., Rubini, A.S., Wundim, A.V., Eyal, O., Talmi-Frank, D., Cury, M.C., Baneth, G., 2014. Prevalence and molecular characterization of Hepatozoon canis in dogs from urban and rural areas in southeast Brazil. Res, Vet. Sci. 97, 326-329.

Mogollon-Pasapera, E., Otvos Jr., L., Giordano, A., Cassone, M., 2009. Bartonella: emerging pathogen or emerging awareness? Int. J. Infect. Dis. 13, 3-8.

Moraes-Filho, J., Marcili, A., Nieri-Bastos, F.A., Richtzenhain, L.J., Labruna, M.B., 2011. Genetic analysis of ticks belonging to the Rhipicephalus sanguineus group in Latin America. Acta Trop. 117, 51-55.

Moraes-Filho, J., Krawczac, F.S., Soares, J.F., Labruna, M.B., 2015. Comparative evaluation of the vector competence of four South American populations of the Rhipichephalus sanguineus group for the bacterium Ehrlichia canis, the agent of canine monocytic ehrlichiosis. PLoS One 10, 1-16.

Murphy, G.L., Ewing, S.A., Whitworth, L.C., Fox, J.C., Kocan, A.A., 1998. A molecular and serologic survey of Ehrlichia canis E. chaffeensis, and E. ewingii in dogs and ticks from Oklahoma. Vet. Parasitol. 79, 325-339.

O’Dwyer, L.H., Moço, T.C., Paduan Kdos, S., Spenassatto, C., da Silva, R.J., Ribolla, P.E., 2013. Description of three new species of Hepatozoon (Apicomplexa, Hepatozoidae) fromRattlesnakes (Crotalusdurissus terrificus) based on molecular, morphometri and morphologic characters. Exp. Parasitol. 135, 200-207.

Passos, L.M.F., Geigerb, S.M., Ribeiro, M.F.B., Pfisterb, K., Zahler-Rinder First, M., 2005. Molecular detection of Babesia vogeli in dogs from Brazil. Vet. Parasitol. $127,81-85$.

Pestana, B.R., 1910. O nambyuvú. Rev. Med. 22, 423-426.

Reis, C., Cote, M., Le Rhun, D., Lecuelle, B., Levin, M.L., Vayssier-Taussat, S., Bonnet, S.I., 2011. Vector competence of the tick Ixodes ricinus for transmission of Bartonella birtlesii. PLoS Neg. Trop. Dis. 5, 1-6.

Rubini, A.S., dos S, Paduan K., Cavalcante, G.G., Ribolla, P.E.M., O’Dwyer, L.H., 2005. Molecular identification and characterization of canine Hepatozoon species from Brazil. Parasitol. Res. 97, 91-93.

Rubini, A.S., Paduan K. dos, S., Lopes, V.V.A., O’Dwyer, L.H., 2008. Molecular and parasitological survey of Hepatozoon canis (Apicomplexa Hepatozoidae) in dogs from rural área of São Paulo state. Brazil Parasitol. Res. 102, 895-899.

Santos, H.A., Pires, M.S., Vilela, J.A.R., Santos, T.M., Faccini, J.L.H., Baldani, C.D. Thomé, S.M.G., Sanavria, A., Massard, C.L., 2011. Detection of Anaplasma phagocytophilum in brazilian dogs by real-time polymerase chain reaction. J. Vet. Diagn. Invest. 23, 770-774.

Santos, H.A., Thomé, S.M., Baldani, C.D., Peixoto, M.P., Pires, M.S., 2013. Molecular epidemiology of the emerging zoonosis agent Anaplasma phagocytophilum in dogs and ixodid ticks in Brazil (Foggie,1949). Parasites Vectors 6, 348.
Sarasúa, L.M., Donati, N.R., 1976. Constatación de babesiosis canina em el depto de Artigas (Uruguay). Veterinaria 62, 137-139.

Schnittger, L., Rodriguez, A.E., Florin-Christensen, M., Morrison, D.A., 2012. Babesia: a world emerging. Infect. Genet. Evol. 12, 1788-1809.

Silveira, J.A.G., Rabelo, E.M.L., Lima, P.C.S., Chaves, B.N., Ribeiro, M.F.B., 2014. Post-mortem hemoparasite detection in free-living Brazilian brown brocket deer (Mazama gouazoubira, Fischer 1814). Braz. J. Vet. Parasitol. Jaboticabal. 23 206-215.

Silveira, J.A.G., Valente, P.C.L.G., Paes, P.R.O., Vasconcelos, A.V., Silvestre, B.T., Ribeiro, M.F.B.R., 2015. The first clinical and laboratory evidence of co-infection by Anaplasma phagocytophilum and Ehrlichia canis in a brazilian dog. Ticks Tick Borne Dis. 6, 242-245.

Soares, J.F., Girotto, A., Brandão, P.E., da Silva, A.S., França, R.T., Lopes, S.T.A., LLopes, S.T.A., Labruna, M.B., 2011. Detection and molecular characterization of a canine piroplasm from Brazil. Vet. Parasitol. 180, 203-208.

Soares, J.F., Dall'Agnol, B., Costa, F.B., Krawczaka, F.S., Comerlatoc, A.T., Rossatod, B.C.D., Linck, C.M., Vieira, M.I.B., Martins, J.R., Reck, J., Labruna, M.B., 2014. Natural infection of the wild canid, Cerdocyon thous, with the piroplasmid Rangelia vitalii in Brazil. Vet. Parasitol. 202, 156-163.

Soares, J.F., Carvalho, L., Maya, L., Dutra, F., Venzal, J.M., Labruna, M.B., 2015. Molecular detection of Rangelia vitalli in domestic dogs from Uruguay. Vet. Parasitol. 201, 98-101.

Solano-Gallego Baneth, L., Baneth, G., 2011. Babesiosis in dogs and cats-expanding parasitological and clinical spectra. Vet. Parasitol. 181, 48-60.

Sousa, K.C., André, M.R., Herrera, H.M., Andrade, G.B., Jusi, M.M.G., Santos, L.L., Barreto, W.T.G., Machado, R.Z., de Oliveira, G.P., 2013. Molecular and serological detection of tick-borne pathogens in dogs from an area endemic for Leishmania infantum in Mato Grosso do Sul, Brazil. Rev. Bras. Parasitol. Vet. 22, 525-531.

Souza, A.M., Almeida, D.N.P., Guterres, A., Gomes, R., Favacho, A.R.M., Moreira, N.S. Maia, L.M.P., Filho, R.A.T., Cerqueira, A.M.F., Lemos, E.R.S., Almosny, N.R.P., 2010. Bartonelose: análise molecular e sorológica em gatos do Rio de Janeiro Brasil. Rev. Bras. Ciên. Vet. 17, 7-11.

Spolidorio, M.G., Labruna, M.B., Zago, A.M., Donatele, D.M., Caliari, K.M., Yoshinari, N.H., 2009. Hepatozoon canis infecting dogs in the State of Epírito Santo, southeastern Brazil. Vet. Parasitol. 163, 357-361.

Staggemeier, R., Venker, C.A., Klein, D.H., Petry, M., Spilki, F.R., Cantarelli, V.V., 2010. Prevalence of Bartonella henselae and Bartonella clarridgeiae in cats in the south of Brazil: a molecular study. Mem. Inst. Oswaldo Cruz 105, 873-878.

Staggemeier, R., Pilger, D.A., Spilki, F.R., Cantarelli, V.V., 2014. Multiplex SYBR green-real time PCR (qPCR) assay for the detection and differentiation of Bartonella hanselae and Bartonella clarridgeiae in cats. Rev. Inst. Med. Trop. São Paulo 56, 93-95.

Stamatakis, A., Hoover, P., Rougemont, J., 2008. A rapid bootstrap algorithm for the RAxML Web servers. Soc. Syst. Biol. 57, 758-771.

Stover, B.C., Muller, K.F., 2010. TreeGraph 2: Combining and visualizing evidence from different phylogenetic analyses. BMC Bioinf. 11, 1-9.

Telford, S.R., Wormser, G.P., 2010. Bartonella spp. transmission by ticks not established. Emerging Infect. Dis. 16, 379-384.

Thompson, J.D., Higgins, D.G., Gibson, T.J., 1994. CLUSTAL W: improving the sensitivity of progressive multiple sequence alignment through sequence weighting, position specific gap penalties and weight matrix choice. Acids Res. 22, $1673-4680$

Trapp, S.M., Messick, J.B., Vidotto, O., Jojima, F.S., Morais, H.S.A., 2006. Babesia gibsoni genotype Asia in dogs from Brazil. Vet. Parasitol. 141, 177-180.

Venzal, J.M., Féliz, M.L., Olsmos, A., Mangold, A.J., Guglielmone, A.A., 2005. A collection of ticks (Ixodidae) from birds in Uruguay. Exp. Appl. Acarol. 36, 325-331.

Vieira R.F. da, C., Vieira, T.S.W.J., do A.G, Nascimento D., Martins, T.F., Krawczak, F.S., Labruna, M.B., Chandrashekar, R., Marcondes, M., Biondo, A.W., Vidotto, O. 2013. Serological survey of Ehrlichia species in dogs, horses and humans: zoonotic scenery in a rural settlement from southern Brazil. Rev. Int. Med. Trop. 55, 335-340.

Vilhena, H., Díaz, V.L.M., Cardoso, L., Vieira, L., Altet, L., Francino, O., Pastor, J., Silvestre-Ferreira, A.C., 2013. Feline vector-borne pathogens in the north and centre of Portugal. Parasites Vectors 6, 1-6.

Yao, C., Zhu, C., Pan, X., Hua, X., Yuan, C., 2011. A review of the prevalence of emerging Bartonellosis in humans and animals in China. Afr. J. Microbiol. Res. $5,4248-4252$.

Yuasa, Y., Hsu, T.-H., Chou, C.-C., Huang, C.-C., Huang, W.-C., Chang, C.-C., 2012. The comparison of spatial variation and risk factors between mosquito-borne and tick-borne diseases: seroepidemiology of Ehrlichia canis, Anaplasma species, and Dirofilaria immitis in dogs. Comp. Immunol. Microbiol. Inf. Dis. 35, 599-606. 